\title{
Manažment emergentných kardiologických stavov u pacientov so suspektnou alebo potvrdenou infekciou COVID-19
}

\section{Odporúčanie Slovenskej kardiologickej spoločnosti zo dňa 14. 4. 2020}

\author{
Autori: Martin Studenčan, Martin Hudec \\ Oponenti: Robert Hatala, Martin Dúbrava
}

\section{Úvod}

Dokumenty Ministerstva zdravotníctva Slovenskej republiky (MZ SR) neriešia podrobne otázky pacientov s emergentným kardiologickým stavom so súbežným suspektným alebo potvrdeným ochorením COVID-19 (pacient). MZ SR odporúča riešit niektoré akútne kardiologické stavy na pracoviskách urgentného príjmu. (Z dôvodov rýchleho poskytnutia kritickej terapie u pacientov s respiračným zlyhanim, ale aj ostatnými ochoreniami tzv. "1. hodiny" (akútny infarkt myokardu, cievna mozgová príhoda, sepsa, závažné krvácanie) je možné, že táto starostlivost’ bude v čase núdze poskytovaná už na urgentnom prijme, ešte pred prijatím pacienta na lôžko JIS/ARO ako sa predpokladá v bežných situáciách. Verzia 1.4 k 3.4.2020 MZ SR, odbor ŠPDTP a Národný krízový klinický tím. To je však v podmienkach slovenského zdravotníctva tažko realizovatelné.

Cielom tohto Odporúčania je v súlade s aktuálnymi medicínskymi poznatkami navrhnút: logistiku hospitalizácie pacientov, ochranu zdravotníckeho personálu poskytujúceho pacientovi zdravotnú starostlivost' (ZS), spôsob prevádzky katetrizačnej sály a kardiologickej jednotky intenzívnej starostlivosti (JIS), kde sa pacientovi ZS poskytuje.

\section{Definícia epidemiologických pojmov}

\section{Potvrdený prípad}

Osoba s laboratórnym potvrdením vírusu spôsobujúceho ochorenie COVID-19, bez ohladu na klinické príznaky a symptómy.

\section{Osoba podozrivá z ochorenia}

1. Pacient $\mathrm{s}$ akútnou infekciou dýchacích ciest (náhly nástup aspoň jedného $\mathrm{z}$ nasledujúcich symptómov: kašel', telesná teplota nad $38{ }^{\circ} \mathrm{C}$, dýchavičnost') a bez inej etiológie, ktorá by plne vysvetlovala klinický obraz a s anamnézou cestovania alebo pobytu v krajine/oblasti s lokálnym prenosom alebo prenosom v komunite ${ }^{\star}$ počas 14 dní pred objavením sa symptómov.

alebo

2. Pacient $s$ akútnym respiračným ochorením, ktorý bol v posledných 14 dňoch pred objavením sa symptómov v úzkom kontakte s potvrdeným alebo pravdepodobným prípadom COVID-19.

alebo

3. Pacient so závažnou akútnou respiračnou infekciou (horúčka a aspoň jeden príznak respiračného ochorenia (napríklad kašel', horúčka, dýchavičnost') a vyžadujúci hospitalizáciu (SARI) a bez dalšej etiológie, ktorá by plne vysvetlovala klinický obraz.

* Podla klasifikácie WHO denné aktualizované hlásenia o výskyte ochorenia (COVID-2019) na https://www.who. int/emergencies/diseases/novel-coronavirus-2019/situation-reports/

alebo

4. Pacient, ktorý je v domácej izolácii, u ktorého pretrváva telesná teplota nad $38^{\circ} \mathrm{C}$ štyri a viac dní a nemá cestovatel'skú anamnézu ani nebol v úzkom kontakte s potvrdeným alebo pravdepodobným prípadom COVID-19. alebo

5. Pacient, ktorý je v domácej izolácii a má príznaky respiračného ochorenia a vek nad 65 rokov.

Po hlásení lokálneho prenosu alebo prenosu v komunite $v$ krajine alebo oblasti sa za suspektné prípady považujú všetci pacienti, ktorí majú príznaky akútnej respiračnej infekcie potvrdené VLD/VLDD alebo na APS (Ambulancia pohotovostnej služby).

Osoba v úzkom kontakte s pravdepodobným alebo potvrdeným prípadom ochorenia COVID-19

- Osoba žijúca v rovnakej domácnosti ako prípad s ochorením COVID-19. 
- Osoba, ktorá bola v priamom fyzickom kontakte s prípadom ochorenia COVID-19 (napríklad podaním rúk).

- Osoba, ktorá má nechránený priamy kontakt s infekčnými sekrétmi osoby s ochorením COVID-19 (napríklad kašlaním, dotykom použitých papierových vreckoviek).

- Osoba, ktorá mala úzky kontakt s prípadom COVID-19 do 2 metrov a dlhší ako 15 minút.

- Osoba, ktorá bola v uzavretom priestore (napríklad učebňa, zasadacia miestnost', čakáreň atd'.) s prípadom COVID-19 najmenej 15 minút a vo vzdialenosti menšej ako 2 metre.

- Zdravotnícky pracovník alebo iná osoba poskytujúca priamu starostlivost' o prípad COVID-19 alebo laboratórni pracovníci, ktorí manipulujú so vzorkami prípadu COVID-19 bez odporúčaných OOPP alebo s možným porušením OOPP.

- Osoba v lietadle sediaca v rámci dvoch sedadiel (v lubovolnom smere) od prípadu COVID-19, spolucestujúci alebo osoby poskytujúce starostlivost’ a členovia posádky slúžiaci v časti lietadla, v ktorej sedel prípad (ak je závažnost' príznakov alebo pohyb prípadu naznačuje rozsiahlejšiu expozíciu, cestujúci sediaci v celej časti alebo všetci cestujúci v lietadle sa môžu považovat’ za osoby v úzkom kontakte).

\section{Emergentný kardiologický stav}

Na účely týchto Odporúčaní sa za emergentný stav považuje situácia, ktorú vzhladom na prístrojovú a personálnu náročnost’ potrebnej liečby nie je možné zvládnut’ v podmienkach „COVID oddelenia“ s izolovanými pacientmi, prípadne by takýto postup mohol zhoršit prognózu pacienta, respektíve ohrozit’ ho na živote. Môže íst’ o:

- akútny infarkt myokardu s eleváciou ST segmentu (STEMI),

- akútny infarkt myokardu bez elevácie ST segmentu (non-STEMI) so znakmi/príznakmi hemodynamickej nestability,

- plúcny edém,

- kardiogénny šok,

- plúcnu embóliu s hemodynamickou nestabilitou,

- malígnu komorovú arytmiu,

- kritickú bradyarytmiu vyžadujúcu dočasnú alebo trvalú kardiostimuláciu,

- iný akútny kardiologický stav podla rozhodnutia kardiológa.

Ak u pacienta s kritickým priebehom a nevyhnutnostou umelej plúcnej ventilácie (UPV) na spádovom ARO/COVID oddelení dôjde $\mathrm{k}$ rozvoju STEMI alebo non-STEMI, ten sa nepovažuje za dôvod na jeho preklad do kardiocentra.

Pätina až polovica pacientov s COVID-19 pneumopatiou má signifikantne zvýšené hladiny myokardiálnych biomarkerov, najmä troponínu a BNP, respektíve NT-proBNP (NP).
Preto treba zvýšenie biomarkerov považovat za nešpecifickú odpoved', ktorá úzko súvisí so závažnostou pulmonálneho postihnutia a prognózou pacienta $(2,3)$. Táto humorálna odozva je podmienená najmä generalizovanou tkanivovou hypoxiou postihujúcou vo významnej miere aj myokard mechanizmom zodpovedajúcim infarktu myokardu typu 2. U pacientov s vysokými hladinami NP sa nepotvrdili ani zvýšené komorové plniace tlaky (4). Títo pacienti môžu formálne splńat kritériá non-STEMI, respektíve srdcového zlyhávania, v drvivej väčšine však nevyžadujú revaskularizačnú intervenciu (3). O nej je potrebné uvažovat' jedine pri sprievodných jasných infarktových EKG zmenách a typickej angíne pektoris.

\section{Trombolytická liečba}

U pacientov so STEMI sa trombolýza dá považovat za valídnu alternatívu primárnej perkutánnej koronárnej intervencie (P-PKI), osobitne v prípadoch nedostupnosti katetrizačnej sály (5). V prípade jej nedostupnosti môže kardiológ rozhodnút o alternatívnej reperfúznej liečbe - trombolýze v priestoroch COVID pracoviska, pri komplikovanom priebehu v priestoroch JIS. Za dôvody nedostupnosti sály možno považovat:

- nedostupnost' intervenčného kardiológa alebo dalších členov invazívneho tímu,

- nedostatok osobných ochranných pracovných pomôcok (OOPP),

- odhadované zdržanie P-PKI kvôli potrebnej dezinfekcii a prípravy sály $>60$ minút,

- technická porucha zariadenia sály neodstránitelná do 60 minút.

U pacientov so STEMI plánovaných na trombolytickú liečbu možno odporučit tento antitrombotický režim:

- ASA 200 mg p. o. čím skôr, potom 100 mg denne, dlhodobo;

- klopidogrel 300 mg p. o. (u pacientov nad 75 rokov $75 \mathrm{mg}$ ) čím skôr, potom $75 \mathrm{mg}$ denne, najmenej 12 mesiacov;

- heparín $60 \mathrm{IU} / \mathrm{kg}$ i. v. v prednemocničnej fáze;

- v nemocnici pokračovat' infúziou heparín (podla ACT, dolná hranica) počas 24 - 48 hodín;

- čo najskôr podat trombolýzu:

\begin{tabular}{|c|c|c|}
\hline $\begin{array}{l}\text { Tenektepláza } \\
\text { (TNK-tPA) } \\
\text { (t. č. nedostupná } \\
\text { v SR) }\end{array}$ & 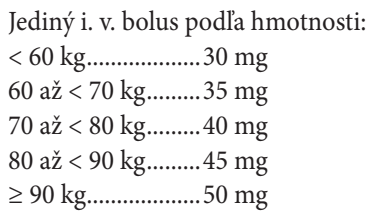 & $\begin{array}{l}\text { U pacientov } \\
\text { nad } 75 \text { rokov } \\
\text { redukcia dávky } \\
\text { o } 50 \%\end{array}$ \\
\hline Altepláza (tPA) & $\begin{array}{l}15 \mathrm{mg} \text { i. v. bolus } \\
0,75 \mathrm{mg} / \mathrm{kg} \text { počas } 30 \mathrm{~min} \\
\text { (max. } 50 \mathrm{mg} \text { ), } \\
\text { potom } 0,5 \mathrm{mg} / \mathrm{kg} \text { počas } 60 \mathrm{~min} \text { i. v. } \\
\text { (max. } 35 \mathrm{mg} \text { ) }\end{array}$ & \\
\hline
\end{tabular}




\section{Logistika hospitalizácie pacientov}

Pacient s emergentným kardiologickým stavom v zmysle týchto Odporúčaní má byt primárne prijatý na špecializované kardiologické pracovisko, a to podla naliehavosti stavu bud' priamo na katetrizačnú sálu, alebo na JIS. Po vykonaní zákroku alebo medikamentóznej stabilizácii môže byt̉ pacient preložený na COVID pracovisko, kde je d’alší kardiologický dohlad zabezpečovaný konziliárne.

Špecializované kardiologické pracovisko $\mathrm{v}$ podmienkach SR vo väčšine prípadov nie je prevádzkované v režime tzv. „červenej zóny“. Špeciálne protiepidemiologické opatrenia a ochrana personálu sú teda zabezpečované „ad hoc“, po oznámení príchodu pacienta.

\section{Ochrana zdravotníckeho personálu}

Vyššie uvedené emergentné kardiologické stavy znamenajú bezprostredné ohrozenie života pacienta a môžu byt spojené s nevyhnutnostou kardiopulmonálnej resuscitácie, intubácie, UPV (a invazívnych kardiologických zákrokov). Tieto výkony patria do kategórie zákrokov s uvolňovaním infikovaného aerosólu, a preto sa na ochranu zdravotníckych pracovníkov (ZP) musia použit nasledovné OOPP:

- respirátor FFP3 [N100] bez výdychového filtra (respirátor FFP3 poskytuje o málo vy̌šiu ochranu ako respirátor FFP2; respirátor FFP2 (dobre priliehajúci, so skontrolovaným tesnením, prekrytý chirurgickým rúškom) možno použit v niektorých prípadoch spojených $\mathrm{s}$ „uvolňovaním aerosólu“, ak respirátor FFP3 nie je dostupný (7),

- ochranný plášt',

- návleky na obuv,

- rukavice,

- čiapka,

- ochrana očí (okuliare/štít): možnost' vstupu vírusu SARS-COV-2 cez sliznicu očí sa považuje za dokázanú (8); odporúčaná norma ochrany BSL-2 hovorí o používaní ochranných okuliarov a ochranného štítu (9), kým Odporúčanie MZSR uvádza okuliare/štít; vzhladom na vyššie uvedené považujeme za vhodné spresnit Odporúčania MZ SR nasledovne: za adekvátnu ochranu očí sa považuje použivanie dobre tesniacich ochranných okuliarov, použitie ochranného štítu je vhodné a považuje sa za dodatočnú ochranu.

Za opakovane dezinfikovatel’né možno považovat' iba ochranné okuliare a štít.

Ak je to možné, miestnost', v ktorej sa poskytuje pacientovi ZS, má byt vzduchotechnicky zabezpečená podtlakom (6).

Odporúča sa, aby sa ZS poskytovala pacientovi za prítomnosti minimálneho počtu ZP. Minimálny počet ZP pri invazívnom zákroku je 5 (invazívny kardiológ, inštrumentárna sestra, pomocná sestra, ošetrovatel, laborant/technik).
$\mathrm{V}$ prípade príjmu pacienta na JIS je minimálny počet ZP zabezpečujúcich starostlivost' o pacienta 4 (kardiológ, 2 sestry, ošetrovatel').

\section{Protiepidemický režim pracoviska}

\section{Katetrizačná sála mimo „červenej zóny“}

Pred vstupom podozrivého alebo infikovaného pacienta do priestorov pracoviska je potrebné zabezpečit, aby sa na pracovisku nenachádzal iný pacient. Ak tam už „nekovidový“ pacient je, o ukončení už prebiehajúceho výkonu rozhodne kardiológ podla diagnózy a klinického stavu oboch pacientov. Ak možno plánovaný zákrok uskutočnit na inej izolovanej sále, uskutoční sa podla rozhodnutia kardiológa. Presun pacienta po spoločnej chodbe možno uskutočnit až po presune "nekovidového" pacienta.

Pred vstupom pacienta do priestorov pracoviska sa všetci ZP, ktorí budú nevyhnutne potrební na poskytnutie špecializovanej ZS, oblečú do OOPP. Ostatní pracovníci sú mimo oddelenia alebo na pracovisku v oddelenej miestnosti.

Pacient musí mat pred vstupom na pracovisko zabezpečenú ochranu úst a nosa chirurgickým rúškom a celé telo zakryté plachtou.

$\mathrm{V}$ priestoroch pracoviska je nevyhnutné minimalizovat pohyb sprevádzajúceho personálu (napríklad posádka ZZS) a limitovat aj ich pohyb na chodbe pred pracoviskom.

Všetky predmety, s ktorými prišiel do kontaktu pacient, prípadne posádka ZZS (napríklad pero, pečiatka, škatulka od liekov), treba priebežne klást do osobitného „špinavého“ kontajnera a neskôr ich dezinfikovat'.

Dezinfekcia olovenej vesty používanej pri zákrokoch je problematická. Aj preto je nevyhnutné prísne ju chránit pred kontaktom s infikovaným povrchom overalu $\mathrm{ZP}$ a pred kontaktom s pacientom. Preto si ZP, ktorý potrebuje olovenú vestu, vždy oblieka dva jednorazové plášte: jeden pod vestu, jeden na ňu. V prípade operatéra a asistujúcej sestry musí byt vonkajší plášt sterilný. Po ukončení výkonu sa všetky použité olovené vesty ukladajú na určené miesto $\mathrm{v}$,špinavej časti pracoviska", kde sú následne dezinfikované, najlepšie sprejovo.

Po skončení výkonu sú pacient a OOPP ZP dekontaminované sprejovým rozprašovačom.

Personál si OOPP vyzlieka až po ukončení dezinfekcie všetkých povrchov v „špinavých“ priestoroch, vrátane transportnej chodby. Použité OOPP sa odkladajú do špeciálnych „špinavých“ kontajnerov/vriec.

$\mathrm{Na}$ dekontamináciu pracoviska po výkone sa používajú prostriedky s potvrdenou úćinnostou proti vírusu SARS-COV 2, najlepšie v sprejovej forme. Prostriedok sa podla návodu nechá pôsobit najmenej 15 minút - do zaschnutia. Následne je možné, nie však povinné, použit aj germicídny žiarič počas 30 minút. Po dezinfekcii možno začat dalš́i zákrok. 
Transport pacienta $\mathrm{z}$ pracoviska na lôžkové oddelenie a následná dezinfekcia trasy jeho pohybu sa riadia vnútornými pokynmi nemocnice.

\section{JIS mimo „červenej zóny“}

Pred vstupom pacienta do priestorov JIS je potrebné zabezpečit, aby s ním neprišli do kontaktu iní pacienti, ktorí už na JIS sú. Pacient je následne umiestnený v samostatnej, izolovanej miestnosti (box).

Pred vstupom pacienta do priestorov JIS sa všetci ZP, ktorí prídu pri jeho umiestňovaní do boxu, oblečú do OOPP. Ostatní ZP pôsobiaci na JIS sú počas umiestňovania pacienta do boxu v oddelenej miestnosti.

Pacient musí mat' pred vstupom na JIS zabezpečenú ochranu úst a nosa chirurgickým rúškom a celé telo zakryté plachtou.

Po umiestnení pacienta do boxu je potrebné primerane zabezpečit dezinfekciu priestorov, ktorými bol transportovaný a až následne umožnit ostatným ZP pohyb v týchto priestoroch.

Počas hospitalizácie pacienta do jeho boxu vstupuje len nevyhnutne potrebný počet $\mathrm{ZP}$, na čo najkratší čas a vždy v OOPP.

Všetky predmety, s ktorými prišiel pacient do kontaktu, treba priebežne klást’ do „špinavého“ kontajnera a neskôr ich podrobit' dezinfekcii.

Po skončení hospitalizácie sa odev pacienta ukladá do osobitného vreca a následne sa dezinfikuje.

Personál sa pri východe $\mathrm{z}$ boxu vyzlieka z OOPP tak, že je najskôr $\mathrm{v}$ boxe pred jeho dverami dekontaminovaný sprejom, potom sa vyzlečie z OOPP a uloží ich do špeciálnych „špinavých“ kontajnerov/vriec a až následne vyjde von $\mathrm{z}$ boxu. Ak má box zriadený špeciálny hygienický filter, ZP sa $z$ OOPP vyzlieka $v$ ňom.

Po prepustení pacienta sa na dekontamináciu boxu používajú prostriedky s potvrdenou účinnostou proti vírusu SARS-COV 2, najlepšie v sprejovej forme. Prostriedok sa podla návodu nechá pôsobit najmenej 15 minút - do zaschnutia. Následne je box germicídne vyžiarený počas 30 minút.

Transport pacienta z JIS na COVID oddelenie alebo iné pracovisko nemocnice na vykonanie diagnostických či terapeutických zákrokov a následná dezinfekcia transportnej trasy sa riadia vnútornými predpismi nemocnice.

\section{Kardiologické pracoviská v „červenej zóne“}

Protiepidemiologický režim sa riadi podla aktuálneho usmernenia MZ SR, hlavného hygienika SR a vnútorného predpisu nemocnice.

\section{Literatúra}

1. Ministerstvo zdravotníctva Slovenskej republiky podla $₫ 45$ ods. 1 písm. c) zákona 576/2004 Z. z. o zdravotnej starostlivosti, službách súvisiacich s poskytovaním zdravotnej starostlivosti a o zmene a doplnení niektorých zákonov v znení neskorších predpisov vydáva štandardný preventívny, diagnostický a terapeutický postup (ŠPDTP): Štandardný postup pre rýchle usmernenia klinického manažmentu detských a dospelých pacientov s novým koronavírusom 2019 (COVID-19) a s pneumóniou.

2. Shi S, Qin M, Shen B, Cai Y, Liu T, Yang F, et al. Association of Cardiac Injury With Mortality in Hospitalized Patients With COVID-19 in Wuhan, China. JAMA Cardiol. 2020 Mar 25. doi: 10.1001/jamacardio.2020.0950

3. Troponin and BNP Use in COVID-19 ACC Magazine.https:// www.acc.org/latest-in-cardiology/articles/2020/03/18/15/25/ troponin-and-bnp-use-in-covid19

4. Chapman XY, et al. High-Sensitivity Cardiac Troponin Can Be An Ally in the Fight Against COVID-19 Circulation 2020 pre-print 10.1161/CIRCULATIONAHA. 120.047008

5. Ibanez B, et al. 2017 ESC Guidelines for the management of acute myocardial infarction in patients presenting with ST-segment elevation: The Task Force for the management of acute myocardial infarction in patients presenting with ST-segment elevation of the European Society of Cardiology (ESC).Eur Heart J2018;39:119-177. doi: 10.1093/eurheartj/ehx393

6. Národný krízový klinický tím (NaKriKT): Aktualizácia používania OOP pri COVID-19 - 29.3.2020 www.standardnepostupy.sk. Verzia $2.0-6.4 .2020$

7. https://www.gov.uk/government/publications/wuhan-novel-coronavirus-infection-prevention-and-control/ updates-to-the-infection-prevention-and-control-guidancefor-covid-19

8. Trish Greenhalgh and Xin Hui Chan, University of Oxford et al. On behalf of the Oxford COVID-19 Evidence Service Team. Centre for Evidence-Based Medicine Nuffield Department of Primary Care Health Sciences University of Oxford. What is the efficacy of eye protection equipment compared to no eye protection equipment in preventing transmission of COVID-19-type respiratory illnesses in primary and community care? April 3, 2020

9. https://consteril.com/biosafety-levels-difference/ 